\title{
Presynaptic Depression of Synaptic Transmission Mediated by Activation of Metabotropic Glutamate Receptors in Rat Neocortex
}

\author{
James P. Burke and John J. Hablitz \\ Neurobiology Research Center and Department of Physiology and Biophysics, University of Alabama at Birmingham, \\ Birmingham, Alabama 35294
}

\begin{abstract}
Conventional intracellular recordings were obtained from layer II-III neurons in adult rat neocortical brain slices. Excitatory and inhibitory (I) postsynaptic potentials (PSPs) were evoked prior to and during bath application of agonists and antagonists of metabotropic glutamate receptors (mGluRs). In the presence of the selective mGluR agonist $1 S, 3 R-1$ aminocyclopentane-1,3-dicarboxylic acid (1S,3R-ACPD; 5$200 \mu \mathrm{M})$, both excitatory and inhibitory components of the evoked PSPs were reversibly reduced. PSPs were significantly, but less effectively, decreased by L-2-amino-4-phosphonobutyric acid. Exposure to putative mGluR antagonists, $\alpha$-methyl-4-carboxyphenylglycine or L-2-amino-3-phosphonopropionic acid, did not inhibit the 1S,3R-ACPD-mediated effect. In the presence of 6,7-dinitroquinoxaline-2,3-dione and D-2-amino-5-phosphonovaleric acid, 1S,3R-ACPD reversibly depressed directly evoked neocortical IPSPs; however, quisqualic acid $(1-10 \mu \mathrm{M})$ did not mimic this effect. Analysis of spontaneous PSPs and paired-pulse facilitation indicated a presynaptic locus of action for $1 S, 3 R-A C P D$ at mGluRs. These findings indicate that a specific mGluR subtype(s) may modulate both excitatory and inhibitory synaptic transmission in the adult rat neocortex via a presynaptic reduction of transmitter release.
\end{abstract}

[Key words: 1S,3R-ACPD, L-AP4, MCPG, glutamate, metabotropic, neocortex, presynaptic]

L-Glutamic acid is widely accepted as the major excitatory neurotransmitter at many synapses in the mammalian CNS. Based on their signal transduction mechanisms, glutamate receptors can be broadly classified into two general groups, ionotropic and metabotropic. The ionotropic excitatory amino acid (EAA) receptor class includes the NMDA and the $\alpha$-amino-3-hydroxy5-methyl-4-isoxazolepropionic acid (AMPA)/kainate receptors. Ionotropic receptors are generally located postsynaptically, are glutamate-gated, nonspecific cation channel complexes, and mediate fast excitatory synaptic transmission (Collingridge and Lester, 1989; Monaghan ct al., 1989; Barnes and Henley, 1992; Nakanishi, 1992). Metabotropic glutamate receptors (mGluRs) are not directly associated with ion fluxes. Instead, they activate second messenger-mediated, biochemical signaling cascades via GTP-binding proteins (G-proteins) (Monaghan et al., 1989; Conn

Received Jan. 6, 1994; Revised Feb. 18, 1994; Accepted March 2, 1994.

This work was supported by MH10150 and NS18145

Correspondence should be addressed to Dr. John J. Hablitz, Neurobiology Rescarch Center, University of Alabama at Birmingham, Birmingham, AL 35294.

Copyright (C) 1994 Society for Neuroscience $0270-6474 / 94 / 145120-11 \$ 05.00 / 0$ and Desai, 1991; Barnes and Henley, 1992; Baskys, 1992; Nakanishi, 1992; Schoepp, 1993; Schoepp and Conn, 1993).

Molecular characterization of mGluRs has revealed a family of mGluR subtypes coupled to G-proteins (Houamed et al., 1991; Masu et al., 1991; Abe et al., 1992; Tanabe et al., 1992; Nakajima et al., 1993). At present, there are at least seven mGluRs, termed mGluR 1-mGluR7 (Houamed et al., 1991; Masu et al., 1991; Abe et al., 1992; Nakanishi, 1992; Tanabe et al., 1992; Nakajima et al., 1993; Saugstad et al., 1993). In situ localization of mRNA coding for the different mGluRs reveals overlapping, but distinct, expression sites, including the neocortex (Abe et al., 1992; Martin et al., 1992; Shigemoto et al., 1992; Tanabe et al., 1992, 1993; Nakajima et al., 1993; Ohishi et al., 1993). The mGluR subtypes also utilize different second-messenger effector systems; for erample, mGluR 1 increases phosphatidylinositol (PI) hydrolysis and mobilizes intracellular $\mathrm{Ca}^{2+}$, liberates arachidonic acid, and inhibits forskolin-stimulated accumulation of intracellular cAMP (Masu et al., 1991; Aramori and Nakanishi, 1992). mGluR5 only induces PI hydrolysis (Abe et al., 1992), while the other mGluRs appear to inhibit forskolin-stimulated accumulation of intracellular cAMP (Prezeau et al., 1992; Tanabe et al., 1992, 1993; Thomsen et al., 1992; Nakajima et al., 1993; Saugstad et al., 1993). While the different subtypes show varied agonist affinities, the most selective agonist described for the mGluRs is the active isomer of trans-1-aminocyclopentane-1,3-dicarboxylic acid, 1S,3RACPD (Schoepp et al., 1990; Conn and Desai, 1991; Baskys, 1992; Nakanishi, 1992; Schoepp, 1993; Schoepp and Conn, 1993).

Electrophysiological studies in a number of brain regions have revealed a wide variety of neuromodulatory actions resulting from mGluR activation. For example, application of glutamate, quisqualic acid, or trans-ACPD hyperpolarizes cerebellar granule cells (Fagni et al., 1991), whereas these mGluR agonists depolarize hippocampal neurons (Stratton et al., 1989, 1990; Charpak et al., 1990; Desai and Conn, 1991; Desai et al., 1992). Excitatory postsynaptic potentials (EPSPs) are reduced by mGluR activation in the hippocampus (Baskys and Malenka, 1991; Desai et al., 1992), cerebellum (Crepel et al., 1991; Glaum et al., 1992), nucleus of the tractus solitarius (Glaum and Miller, 1992), and the striatum (Lovinger, 1991; Calabresi et al., 1992, 1993; Lovinger et al., 1993). mGluR agonists also reduce inhibitory PSPs (IPSPs) in these brain regions (Desai and Conn, 1991; Calabresi et al., 1992; Desai et al., 1992; Glaum and Miller, 1992). Long-term potentiation can be facilitated by mGluR activation in the hippocampal CA 1 region (Aniksztein et al., 1992; Bashir et al., 1993) and in the dorsal lateral septal nucleus (Zheng 
and Gallagher, 1992). mGluR activation can also mediate longterm depression in cerebellar Purkinje cells (Linden et ail., 1991). As a result, there have been numerous theories concerning the role(s) of the mGluR subtypes and their subsequent biochemical cascades in normal synaptic transmission (Schoepp et al., 1990; Anwyl, 1991; Conn and Desai, 1991; Baskys, 1992; Nakanishi, 1992; Schoepp, 1993; Schoepp and Conn, 1993) and in pathological states such as neurotoxicity and epilepsy (Schoepp et al., 1990; Conn and Desai, 1991; Nakanishi, 1992; Schoepp, 1993; Schoepp and Conn, 1993).

Despite their marked expression in the neocortex, the role of mGluRs in normal synaptic transmission in this brain region is unclear. Our goal was to examine the effects of mGluR activation on synaptic transmission in the rat frontal neocortex. Conventional intracellular recording techniques were used to record PSPs evoked by intracortical stimulation. Our results show that synaptic transmission is reversibly depressed during mGluR activation, and the data suggest a presynaptic locus of action.

Preliminary reports of some of these data have been published elsewhere (Burke and Hablitz, 1992).

\section{Materials and Methods}

Slices of frontal neocortex were obtained from adult Sprague-Dawley rats of both sexes (125-250 gm). Rats were decapitated under ether or ketamine $(100 \mathrm{mg} / \mathrm{kg})$ anesthesia, and the brains were quickly dissected out and placed in ice-cold saline for $30-60 \mathrm{sec}$. The tissue was blocked with a razor blade to separate the hemispheres and to remove the caudal and ventral portions of the brain. The tissue block was attached to a Teflon chuck with cyanoacrylate (Superglue). Four or five coronal slices (500 $\mu \mathrm{m}$ thick) of frontal neocortex were prepared on a Vibroslice (Campden Instruments), and incubated in a holding chamber at room temperature for at least $2 \mathrm{hr}$. Single brain slices were transferred to an interface-type recording chamber, and maintained with constant saline perfusion $(1 \mathrm{ml} / \mathrm{min})$. The chamber was warmed slowly to the recording temperature of $34 \pm 1^{\circ} \mathrm{C}$. The extracellular solution consisted of the following (in mM): $\mathrm{NaCl}, 125 ; \mathrm{KCl}, .3 .5 ; \mathrm{NaH}_{2} \mathrm{PO}_{4}, 1.25 ; \mathrm{CaCl}_{2}, 2.5$; $\mathrm{MgSO}_{4}, 1.3 ; \mathrm{NaHCO}_{3}, 26$; glucose, 10 . This solution was continuously perfused with a mixture of $95 \% \mathrm{O}_{2}$ and $5 \% \mathrm{CO}_{2}$ to attain a steady state level of oxygenation and to maintain a $\mathrm{pH}$ of 7.4 .

Conventional intracellular recording electrodes were pulled from filament-containing borosilicate glass tubing $(1.5 \mathrm{~mm}$ o.d.; A-M Systems, Inc.), and filled with $4 \mathrm{M}$ potassium acetate (adjusted to $\mathrm{pH} 7.2$ with acetic acid). Electrode resistances ranged from 50 to $110 \mathrm{M} \Omega$. Recordings were acquired with the use of an Axoclamp 2-A amplifier (Axon Instruments) in bridge mode. Voltage signals werc digitized on line with pCLAMP 5.5 software (Axon Instruments) or were recorded onto videotape via a Neuro-Corder DR-384 (NeuroData Instruments) to be digitized at a later time. Records were stored on disk and analyzed with pCLAMP software. Spontaneous PSPs were digitized and subsequently analyzed using Strathclyde Electrophysiological Software (courtesy of J. Dempster, University of Strathclyde, Glasgow). Neuronal membrane potential was monitored continuously on a Gould RS3200 oscillograph recorder (Gould Inc.). A mono- or bipolar stimulating electrode was placed intracortically in layers IV-V slightly lateral to the recording electrode.

After impalement of layer II-III neurons ( $N=89$ from 70 rats), the resting membrane potential was allowed to stabilize for a minimum of $20 \mathrm{~min}$. Neuronal input resistance was monitored in bridge mode with a $-0.4 \mathrm{nA}$ constant amplitude current pulse of $100 \mathrm{msec}$ duration. All measurements were performed at the original resting membrane potential for each neuron. Constant amplitude current pulses of variable duration were delivered through the stimulating electrode to activate fibers projecting to layer II-III neurons. Postsynaptic potentials (PSPs) in response to increasing stimulus durations (40-180 sec) were evoked at $10-15 \mathrm{sec}$ intervals before, during, and after bath application of putative $\mathrm{mGluR}$ agonists and antagonists. In the presence of 6-cyano7-nitroquinoxaline-2,3-dione (CNQX) and $\mathrm{D}(-) 2$-amino-5-phosphonovaleric acid (D-AP5), the effects of mGluR activation on excitatory amino acid antagonist-resistant PSPs were investigated. The voltage dependence of these directly evoked inhibitory PSPs was determined by injecting constant depolarizing current through the recording electrode. Bridge balance was monitored continuously.

To examine paired pulse facilitation (PPF) of ncocortical PSPs, stimulus parameters (i.e., intensity and duration) that evoked primarily excitatory PSPs were used. Interpulse intervals of 10-200 msec were used. Facilitation was calculated as the ratio between the amplitude of the second (test) response and the first (conditioning) response in a pair. During drug application, PPF was tested with the control intensity and with an increased stimulus intensity (to maintain the amplitude of the first PSP at control levels). Control records were compared to those obtained during mGluR activation.

CNQX, D-AP5, L-2-amino-3-phosphonopropionic acid (L-AP3), L-2amino-4-phosphonobutyric acid (L-AP4), trans-ACPD, 1R,3S-ACPD, $1 S, 3 R$-ACPD, $(R, S)$ - and $(+)-\alpha$-methyl-4-carboxyphenylglycine(MCPG) were purchased from Tocris Neuramin; 3,7-dimethyl-1-propargylxanthine (DMPX), from Research Biochemicals, Inc.; and quisqualic acid, from Cambridge Research Biochemicals Limited. These compounds were dissolved in distilled $\mathrm{H}, \mathrm{O}$ and prepared as $10 \mathrm{~mm}$ stock solutions (except MCPG, 1:1 equivalents of $110 \mathrm{~mm} \mathrm{NaOH}$; and quisqualic acid, $10 \%$ ammonium hydroxide). They were then frozen and added in small aliquots to the physiological saline during the experiment. All compounds were applied via the bath, and each neuron served as its own control.

Each trace shown is the average of two responses to a given stimulus. All values are expressed as mean $\pm S D$, except where noted. Statistical analysis consisted of paired and unpaired $t$ tests. A significance level of 0.05 was used.

\section{Results}

PSPs evoked during the control period were compared to those evoked during bath application of pharmacological agents. Three points of measure were analyzed: peak PSP amplitude in response to minimum stimulation, peak amplitude to maximum stimulation, and the peak amplitude of the delayed depolarizing response to maximum stimulation. Stimulus-response curves were determined for each measurement. Minimum stimulation $(40 \mathrm{sec})$ produced a purely excitatory PSP, whereas the response to maximal stimulation $(180 \mathrm{sec})$ was an EPSP-IPSP complex. The early component of the compound PSP was predominantly excitatory, while the late depolarizing response was primarily a $\mathrm{GABA}_{\mathrm{A}}$ receptor-mediated $\mathrm{Cl}$ conductance (Connors et al., 1988; Sutor and Hablitz, 1989a,b; Hablitz and Sutor, 1990).

trans- $A C P D$ reduces evoked svnaptic transmission in the adult rat neocortex

The evoked PSP to minimum stimulation before and during bath application of $50 \mu \mathbf{M}$ trans-ACPD is shown in Figure $1 \mathrm{~A}$. In this example, only a slight reduction in the peak amplitude was observed (to $96.6 \%$ of control). As shown in Figure $1 B$, however, the response to maximal stimulation was more notably depressed. In this cell, the peak amplitude to maximum stimulation was reduced to $84.8 \%$ of control. The late depolarization was similarly reduced to $77.9 \%$ of control. No change in resting membrane potential (RMP; $-89 \mathrm{mV}$ ) was noted in this cell during trans-ACPD application. Neuronal input resistance $\left(R_{\mathrm{in}}\right)$ prior to and during drug application was $24.9 \mathrm{M} \Omega$ and $27.8 \mathrm{M} \Omega$, respectively. In Figure $1, C$ and $D$ present input-output curves for the peak amplitudes of the early response and the late depolarization, respectively. These plots show that synaptic potentials were reduced at all but the weakest stimulus strengths. Mean values for these data with 20-50 $\mu \mathrm{M}$ trans-ACPD $(N=$ 8 ) are presented in Table 1.

\section{IS,3R-ACPD is the active stereoisomer}

trans-ACPD is a conformationally restricted analog of the extended form of glutamate, consisting of a $1: 1$ racemic mixture 


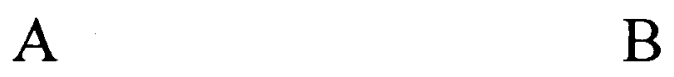

Figure 1. trans-ACPD decreases synaptic transmission in the adult neocortex. Intracellular recordings of evoked synaptic activity in a layer II-III neuron are shown in $A$ and $B$. $A$, Minimum electrical stimulation produces a small PSP that was marginally inhibited by $50 \mu \mathrm{M}$ trans-ACPD ( $96.6 \%$ of control). $B$, In the same neuron, more intense stimulation produced an EPSP-IPSP complex. IPSP is depolarizing due to the high RMP $(-89 \mathrm{mV})$. Both excitatory and inhibitory components are reduced by trans-ACPD (to $84.8 \%$ and $77.9 \%$ of control, respectively). $C$ and $D$. Plot of response amplitude as a function of stimulus intensity for the peak and late depolarizing responses, respectively, during control $(\boldsymbol{O})$ and in the presence of drug $(\square)$.

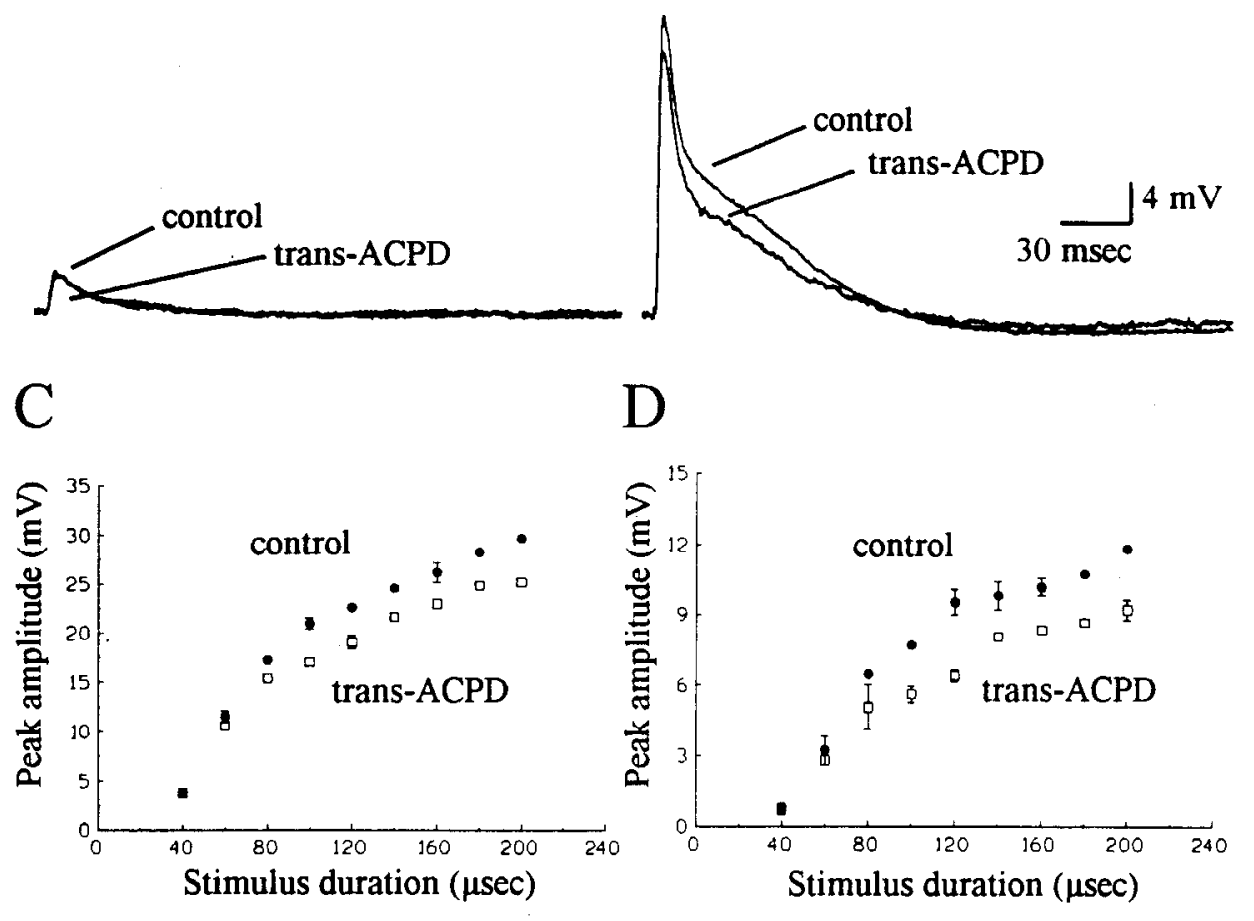

of $1 S, 3 R$ - and $1 R, 3 S$-ACPD. Some studies have shown that $1 S, 3 R$-ACPD is the active isomer at mGluRs (Irving et al., 1990; Schoepp et al., 1991b), whereas others report that both enantiomers are full agonists for mGluRs coupled to PI hydrolysis and intracellular $\mathrm{Ca}^{2+}$ mobilization (Manzoni et al., 1992). We therefore tested the effects of bath-applied $1 S, 3 R$ - and $1 R, 3 S$ ACPD on synaptic transmission in the neocortex.

Bath application of $1 S, 3 R$-ACPD $(N=33)$ resulted in a reduction of evoked synaptic responses in the adult neocortex. As shown in Figure 2, all components of the evoked PSPs were markedly depressed during $100 \mu \mathrm{M} 1 S, 3 R$-ACPD application. In Figure $2 A$, the peak amplitude of an evoked PSP is plotted against time during $1 S, 3 R$-ACPD application $(27 \mathrm{~min})$ and its subsequent washout. In this cell, the response to minimum stimulation was reduced to $34.7 \%$ of control; the peak response and the late depolarization to maximum stimulation were reduced to $47.2 \%$ and $45.2 \%$, respectively (Fig. $2 B$ ). During drug application, $R_{\text {in }}$ was slightly increased (16.8 vs $20.1 \mathrm{M} \Omega$ ), and the RMP was depolarized from $-88 \mathrm{mV}$ to $-84 \mathrm{mV}$. Upon washout of $1 S, 3 R-A C P D$, the evoked PSPs returned to their control amplitudes; $R_{\mathrm{in}}$ also returned to baseline. RMP repolarized by $1 \mathrm{mV}$ with washout.

Catania et al. (1992) and Lonart et al. (1992) each describe a rapid and long-lasting desensitization of mGluR-mediated PI hydrolysis with extended exposure to mGluR agonists. We observed no desensitization of the response to $1 S, 3 R$-ACPD, as this agonist could be reapplied to the same neocortical brain slice $(N=3$, data not shown), producing similar results each time. Additionally, no desensitization of the $1 S, 3 R$-ACPD-mediated effects was observed during application periods up to 115 $\min (N=4)$.

Unlike the active isomer, $1 R, 3 S$-ACPD did not depress synaptic transmission, nor were effects on $R_{\text {in }}$ or RMP observed.
In Figure $2 C$, the peak PSP amplitude to minimal stimulation was $99.4 \%$ of control; the peak response to maximum stimulation was $100.4 \%$ of control during $1 R, 3 S$-ACPD application, and the late depolarization was $89.7 \%$ of control. As shown in Table 1, synaptic and membrane properties varied less than $10 \%$ from control values in the presence of $200 \mu \mathrm{M} 1 R, 3 S$-ACPD $(N=3)$.

\section{Dose dependence of $1 \mathrm{~S}, 3 \mathrm{R}-A C P D$ effects}

The dose-response curves for the three measured components of the evoked PSPs are shown in Figure 3. Responses have been normalized to the maximum percentage reduction produced by $200 \mu \mathrm{M} 1 S, 3 R$-ACPD $(N=12)$ for each of the three PSP measurements (Table 1). The $\mathrm{EC}_{50}$ for the $\mathrm{mGluR-mediated} \mathrm{reduc-}$ tion of the peak response to minimum stimulation by $1 S, 3 R$-ACPD was $30.23 \mu \mathrm{M}$. The peak response and the late depolarizing response to maximum stimulation had similar $\mathrm{EC}_{50}$ values of $33.57 \mu \mathrm{M}$ and $32.66 \mu \mathrm{M}$, respectively.

Seventeen of 40 cells tested with 5-200 $\mu_{\mathrm{M}} 1 S, 3 R$-ACPD depolarized slightly during drug application (depolarizations ranged from 1 to $4 \mathrm{mV}$ ). Statistically significant differences in RMP and $R_{\text {in }}$ were noted only for 100 and $200 \mu \mathrm{M} 1 S, 3 R$-ACPD (Table 1). Pooled data from all experiments indicate a statistically significant trend toward depolarization $(-88.6 \pm 3.1$ and $-87.7 \pm 3.0 \mathrm{mV}$, control vs drug, respectively) and an increased $R_{\text {in }}$, measured at the original $\operatorname{RMP}(20.7 \pm 4.3$ and $22.4 \pm 4.6$ $\mathrm{M} \Omega$, control vs drug, respectively) during the application of $1 S, 3 R$-ACPD.

\section{$L-A P 4$ reduces postsynaptic potentials}

L-2-Amino-4-phosphonobutyric acid (L-AP4) has been reported to antagonize some responses mediated by $\mathrm{mGluR}$ activation (Schoepp and Johnson, 1988; Zheng and Gallagher, 1992). 

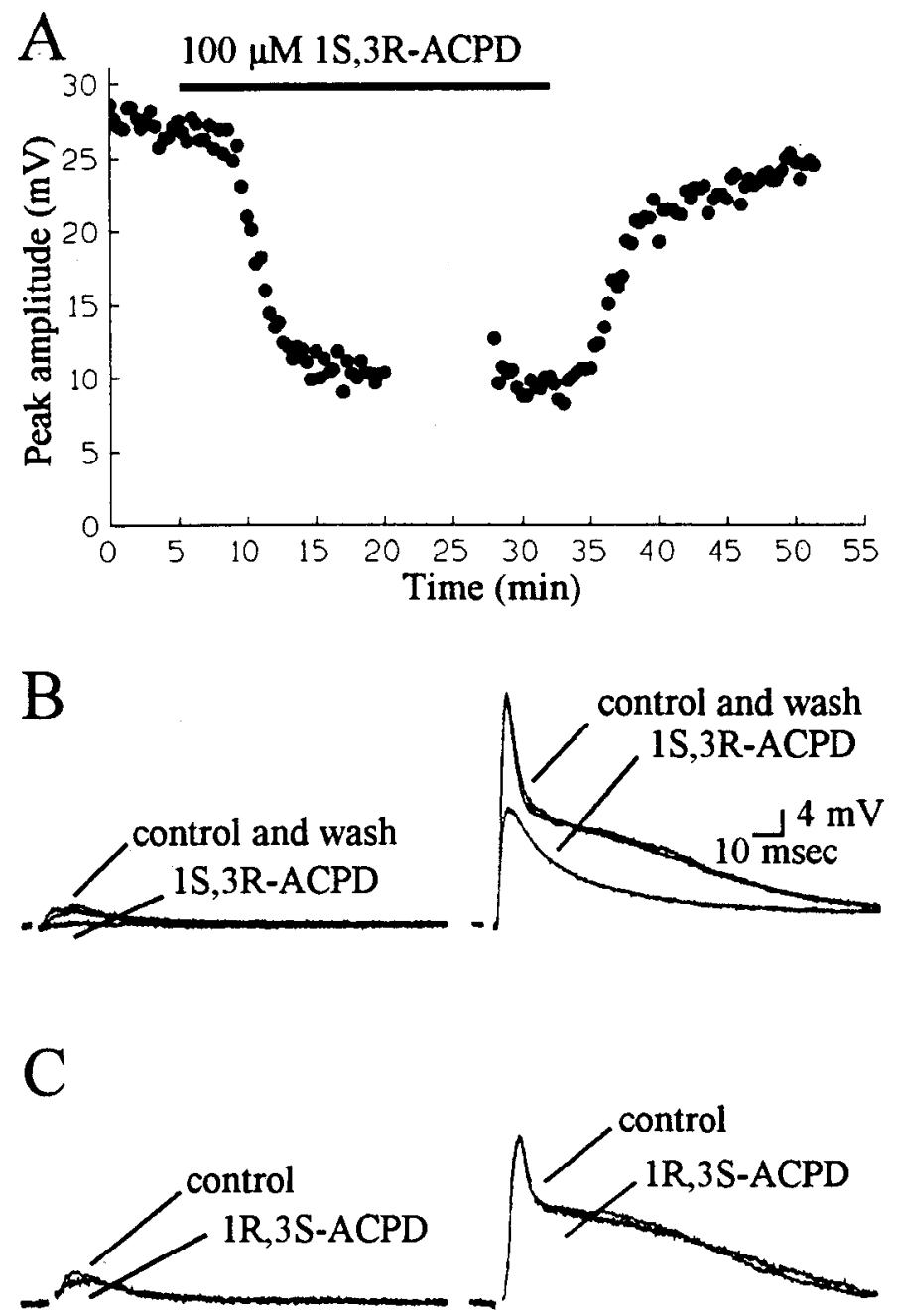

Figure 2. $1 S, 3 R$-ACPD reversibly reduces synaptic potentials. $A$, Plot of EPSP amplitude as a function of time. Bath application of $1 S, 3 R$ ACPD $(100 \mu \mathrm{M})$ for the time indicated by the horizontal bar reduced the peak amplitude of evoked PSPs to $47.2 \%$ of control. After 27 min of exposure, response amplitude recovered to control levels after removal of ACPD. $B$. Specinten records of PSPs in a layer II-III neuron. RMP was $-89 \mathrm{mV}$. Evoked PSPs to minimum (left traces) and maximum (right traces) stimulation were reversibly inhibited by $1 S, 3 R$ ACPD. $C$, As in $B$, but recordings from another neuron; RMP was -88 $\mathrm{mV} .1 R, 3 S$-ACPD did not reduce synaptic transmission in the adult rat neocortex.

However, L-AP4 also activates a presynaptic glutamate receptor that depresses synaptic transmission (Harris and Cotman, 1983; Cotman et al., 1986; Forsythe and Clements, 1990; Baskys and Malenka, 1991; Rainnie and Shinnick-Gallagher, 1992; Calabresi et al., 1993) via a G-protein-coupled mechanism (Trombley and Westbrook, 1992). This electrophysiologically defined receptor has been termed the AP4 receptor (Collingridge and Lester, 1989; Monaghan et al., 1989). Recently, L-AP4 has been shown to activate the mGluR4 subtype, which is negatively coupled to the cAMP cascade (Thomsen et al., 1992; Tanabe et al., 1993), and it has been suggested that the AP4 receptor and the mGluR4 are the same glutamate receptor subtype (Nakanishi, 1992; Thomsen et al., 1992; Schoepp and Conn, 1993; Tanabe et al., 1993; but see Trombley and Westbrook, 1992).

We wished to determine the effects of bath-applied L-AP4 on synaptic transmission and passive membrane properties in the

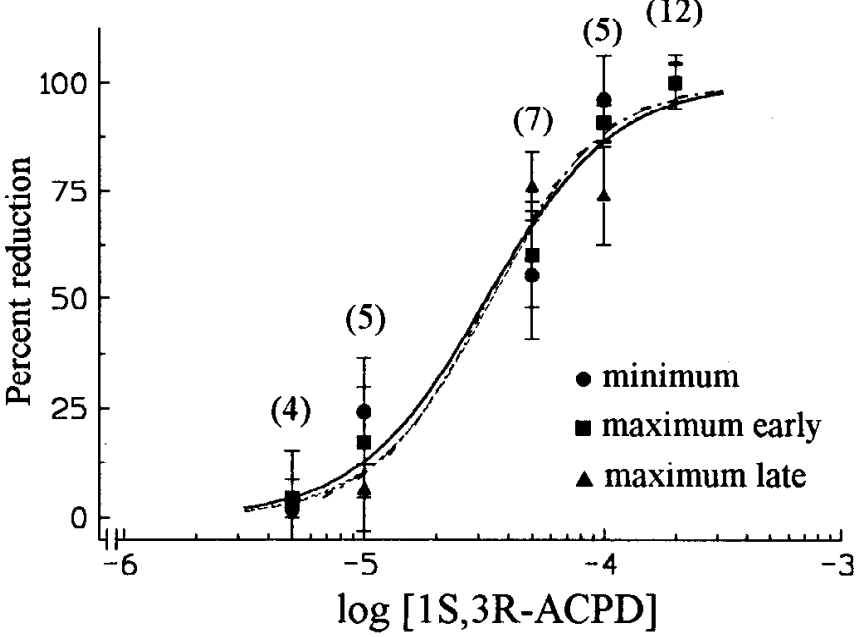

Figure 3. Dose-response relations for reductions in synaptic transmission by $m$ GluR agonists. The percentage reduction in PSP amplitude is plotted as a function of the $\log 1 S, 3 R$ ACPD concentration. Data were normalized to the response produced by $200 \mu \mathrm{M} 1 S, 3 R$-ACPD. The maximum reductions observed were: for minimum stimulation, $68.3 \%(\circlearrowleft)$; for peak amplitude to maximum stimulation, $57.8 \%(\square)$; and for late depolarization to maximum stimulation, $74.1 \%$ (A). Means \pm SEM are displayed. Three curves are shown superimposed. $E_{5(1)}$ values were similar for each PSP measurement (see Results).

adult neocortex prior to examining its putative antagonism of mGluRs. Bath application of L-AP4 (200-1000 $\mu \mathrm{M}, N=4)$ consistently reduced evoked PSPs, but had no effect on $R_{\text {in }}$ or RMP (Table 1). An example of the L-AP4-mediated effect is shown in Figure 4. The minimum response was reduced to $65.7 \%$ of control by $200 \mu \mathrm{M}$ L-AP4 (Fig. $4 A$ ). In Figure $4 B$, the peak response to maximum stimulation was reduced to $71.9 \%$, and the late depolarization to maximum stimulation was similarly reduced to $58.5 \%$ of control. The input-output relationships for the early and late PSP measurements are shown in Figure 4, $C$ and $D$, respectively. Responses were reduced at all but the smallest stimulus strengths. The effects of mGluR agonists on synaptic and membrane properties of neocortical neurons are summarized in Table 1.

\section{Putative $m G$ GuR antagonists}

Recent studies have indicated that $(R, S)$ - $\alpha$-methyl-4-carboxyphenylglycine (MCPG), or its active form, ( I )-MCPG, is a competitive mGluR antagonist (Bashir et al., 1993; Eaton et al., 1993; Frenguelli et al., 1993; Jane et al., 1993). Bath application of (+)-MCPG (250-1000 $\mu \mathrm{M}, N=6)$ for $30 \mathrm{~min}$ did not affect synaptic transmission in neocortical slices. When $200 \mu \mathrm{M} 1 S, 3 R$ ACPD was bath applied to MCPG-treated slices, little antagonism of the mGluR-mediated synaptic depression was observed. PSPs to minimum stimulation were $92.0 \pm 22.8 \%$ of control amplitude in MCPG; these PSPs were reduced to 56.4 $\pm 26.9 \%$ with ACPD application (Fig. $5 \mathrm{~A}$ ). In the presence of MCPG, the peak PSP amplitude to maximum stimulation was $103.6 \pm 11.9 \%$ of control. $1 S, 3 R$-ACPD reduced these responses to $58.7 \pm 13.1 \%$ (Fig. $5 B$ ). During MCPG application, the late depolarization to maximum stimulation was $102.3 \pm$ $15.6 \%$ of control amplitude, and was reduced to $59.4 \pm 24.1 \%$ (Fig. $5 C$ ). These changes were statistically significant. Thus, MCPG does not antagonize $m G$ luR-mediated synaptic depression in the adult neocortex. Effective MCPG concentrations 


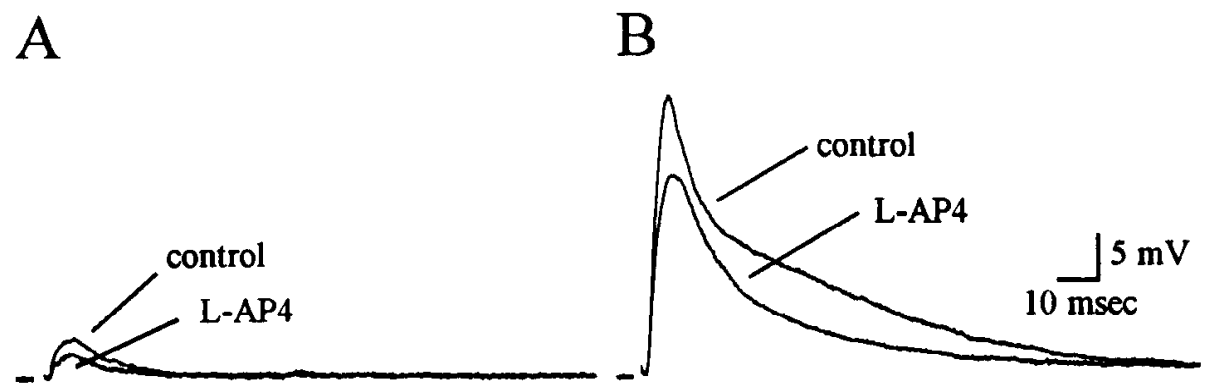

Figure 4. L-AP4 depresses synaptic responses in the neocortex. Intracellular recordings of responses to intracortical stimulation were obtained before and during bath application of L-AP4; RMP was $-90 \mathrm{mV}$. $A$ and $B$, L-AP4 $(200 \mu \mathrm{M})$ reduced PSPs evoked by minimum ( $A$, to $65.7 \%$ of control) and maximum stimulation ( $B$, to $71.9 \%$ and $58.5 \%$ of control, peak and late response, respectively). $C$ and $D$, Inputoutput relationships for peak amplitude and late depolarizing response, respectively, before (@) and during L-AP4 exposure ( $\square$ ). Responses were reduced at all but the smallest stimulus strengths.
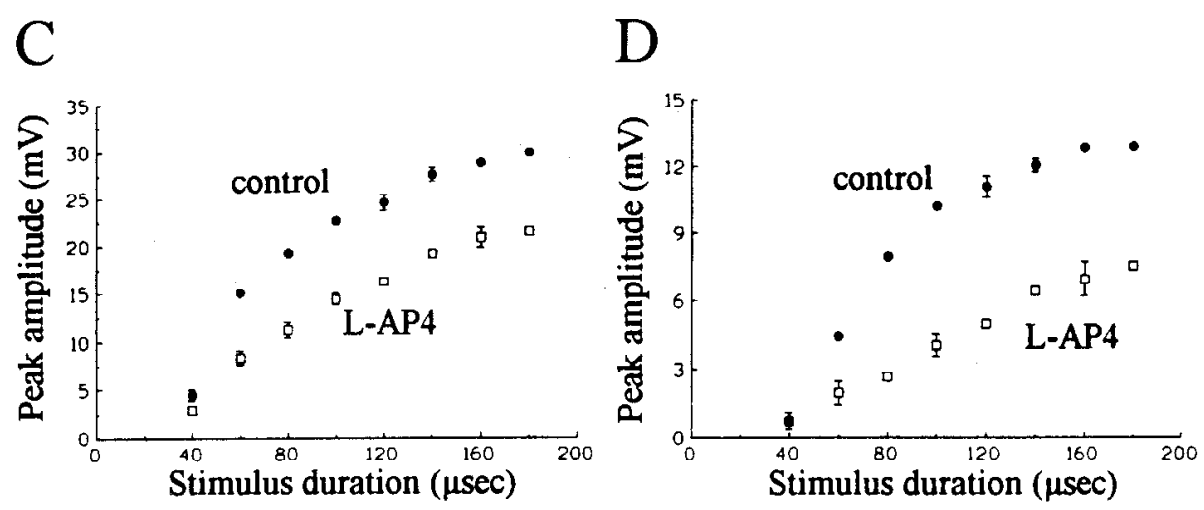

were achieved in the slice, because $1 S, 3 R$-ACPD-mediated changes in spike accommodation (J. P. Burke and J. J. Hablitz, unpublished observations) were blocked. This suggests that MCPG is an effective antagonist at postsynaptic mGluRs in the adult neocortex, but may be less effective (or inactive) at presynaptic mGluRs (see Frenguelli et al., 1993).

High concentrations of $\mathrm{L}$-2-amino-3-phosphonopropionic acid (L-AP3) have been shown to block MGluR-mediated PI hydrolysis (Schoepp and Johnson, 1989; Houamed et al., 1991; Desai et al., 1992), intracellular $\mathrm{Ca}^{2+}$ mobilization (Irving et al., 1990), and increased cAMP accumulation (Winder and Conn, 1993). L-AP3 also has been reported to block some electrophysiological effects of mGluR activation (Izumi et al., 1991;
Linden et al., 1991; Zheng and Gallagher, 1992; Sahara and Westbrook, 1993), whereas other studies show no mGluR antagonism by L-AP3 (Stratton et al., 1990; Charpak and Gähwiler, 1991; Desai et al., 1992; Glaum el al., 1992; Hu and Storm, 1992; Bashir et al., 1993; Lovinger et al., 1993).

We found that bath application of L-AP3 (200-1000 $\mu \mathrm{M}, N$ $=3$ ) was without effect on synaptic transmission in the neocortex. When slices were bathed in L-AP3 for at least $30 \mathrm{~min}$ prior to applying $1 S, 3 R-A C P D(100-200 \mu \mathbf{M})$, no antagonism of the mGluR-mediated synaptic depression was observed. These concentrations of ACPD were selected because of their reliability in reducing PSP amplitude and because of the general ineffectiveness of lower $\Lambda$ CPD concentrations (see Table 1).

Table 1. Agonist effects at mGluRs

\begin{tabular}{|c|c|c|c|c|c|c|c|c|}
\hline \multirow[b]{2}{*}{$\underline{\text { Drug }}$} & \multirow[b]{2}{*}{$\mu \mathrm{M}$} & \multicolumn{2}{|l|}{$\mathrm{RMP}(\mathrm{mV})$} & \multicolumn{2}{|l|}{$R_{\text {in }}(\mathrm{M} \Omega)^{a}$} & \multirow{2}{*}{$\begin{array}{l}\text { Minimum } \\
\% \text { change }\end{array}$} & \multirow{2}{*}{$\begin{array}{l}\text { Max early } \\
\% \text { change }\end{array}$} & \multirow{2}{*}{$\begin{array}{l}\text { Max late } \\
\% \text { change }\end{array}$} \\
\hline & & Control & Drug & Control & Drug & & & \\
\hline trans-ACPD & $20-50$ & $-80.1 \pm 4.7$ & $-77.9 \pm 6.5^{*}$ & $24.5 \pm 3.6$ & $21.8 \pm 5.2$ & $-22.8 \pm 23.5$ & $-22.7 \pm 14.6^{*}$ & $-23.3 \pm 25.2^{*}$ \\
\hline \multirow[t]{5}{*}{$1 S, 3 R$-ACPD } & 5 & $-87.5 \pm 4.5$ & $-87.8 \pm 3.9$ & $19.5 \pm 3.9$ & $20.6 \pm 4.0$ & $-1.3 \pm 2.5$ & $-2.5 \pm 5.0$ & $-3.2 \pm 15.8$ \\
\hline & 10 & $-91.6 \pm 1.5$ & $-90.0 \pm 1.2$ & $18.8 \pm 2.9$ & $20.0 \pm 4.5$ & $-18.5 \pm 18.8$ & $-9.9 \pm 16.5$ & $-4.7 \pm 15.7$ \\
\hline & 50 & $-89.0 \pm 3.1$ & $-88.4 \pm 3.0$ & $23.7 \pm 5.3$ & $25.2 \pm 6.4$ & $-37.9 \pm 26.5^{*}$ & $-39.3 \pm 12.7^{*}$ & $-55.6 \pm 15.4^{*}$ \\
\hline & 100 & $-87.9 \pm 2.8$ & $-86.4 \pm 3.2^{*}$ & $20.4 \pm 3.7$ & $21.8 \pm 2.6^{*}$ & $-65.6 \pm 15.1^{*}$ & $-52.6 \pm 5.4^{*}$ & $-53.9 \pm 18.6^{*}$ \\
\hline & 200 & $-88.1 \pm 30$ & $-87.3 \pm 2.8^{*}$ & $20.8 \pm 4.8$ & $22.9 \pm 5.2^{*}$ & $-68.3 \pm 8.0^{*}$ & $-57.8 \pm 12.6^{*}$ & $-74.1 \pm 11.0^{*}$ \\
\hline $1 R, 3 S-\mathrm{ACPD}$ & 200 & $-87.7 \pm 0.6$ & $-88.0 \pm 2.6$ & $29.8 \pm 9.2$ & $29.0 \pm 8.8$ & $-4.3 \pm 4.8$ & $1.4 \pm 7.3$ & $-7.6 \pm 3.8$ \\
\hline L-AP4 & $200-1000$ & $-84.5 \pm 9.1$ & $-86.0 \pm 6.7$ & $28.6 \pm 9.9$ & $28.4 \pm 12.2$ & $-19.0 \pm 23.5$ & $-24.9 \pm 10.0^{*}$ & $-35.7 \pm 5.3^{*}$ \\
\hline
\end{tabular}

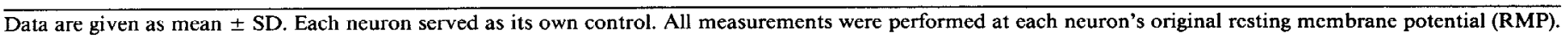

"Neuronal input resistance $\left(R_{\text {in }}\right)$ was tested with $-0.4 \mathrm{nA}$ constant current pulses of $100 \mathrm{msec}$ duration.

"The percentage change in peak PSP amplitude in response to minimum intracortical stimulation $(40 \mu \mathrm{sec})$.

The percentage change in peak PSP amplitude in response to maximum intracortical stimulation (180 $\mu \mathrm{sec})$.

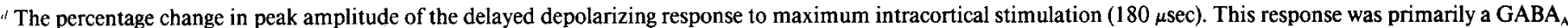
receptor-mediated $\mathrm{Cl}^{-}$conductance (Connors et al, 1988; Sutor and Hablitz, 1989a, b; Hablitz and Sutor, 1990).

* Significant differences between control and drug conditions $(p<0.05$, paired Student's $t$ test). 
PSPs to minimum stimulation were $103.1 \pm 8.4 \%$ of control amplitude in L-AP3; these PSPs were reduced to $51.8 \pm 17.8 \%$ with ACPD application (Fig. 5A). In the presence of L-AP3, the peak PSP amplitude to maximum stimulation was $99.0 \pm 8.4 \%$ of control. IS,3R-ACPD reduced these responses to $47.1 \pm$ $5.9 \%$ (Fig. 5B). During L-AP3 application, the late depolarization to maximum stimulation was $93.1 \pm 11.8 \%$ of control amplitude; this response was reduced to $26.1 \pm 7.0 \%$ (Fig. $5 C$ ). Differences between PSP amplitudes in the presence of L-AP3 and in the combined presence of L-AP3 and ACPD were significant for responses evoked by both minimum and maximum stimulation. L-AP3 also did not antagonize postsynaptic effects of mGluR activation (Burke and Hablitz, unpublished observations). Thus, L-AP3 is not an effective agonist at neocortical mGluRs mediating electrophysiologic responses.

\section{Adenosine receptors do not mediate the reduction in synaptic transinission by $A C P D$}

Activation of hippocampal adenosine receptors has been shown to decrease synaptic transmission via a presynaptic mechanism (Yoon and Rothman, 1991; Prince and Stevens, 1992; Thompson et al., 1992). Recent reports have demonstrated interactions between $\mathrm{mGluRs}$ and adrenergic receptors that increase cAMP accumulation in hippocampus (Winder and Conn, 1993) and decrease accumulation in the cerebral cortex (Cartmell et al., 1993). To investigate the possibility that endogenous adenosine might play a role in the effects of mGluR activation in the neocortex, 3,7-dimethyl-1-propargylxanthine (DMPX; 50-100 $\mu \mathrm{M}, N=2$ ) was bath applied at least $30 \mathrm{~min}$ prior to $1 S, 3 R$ ACPD application. DMPX is a selective $A_{2}$ receptor antagonist with an $E_{50}$ of $11 \pm 4 \mu \mathrm{M}$; the $E_{50}$ for the $A_{1}$ receptor is 45 $\pm 5 \mu \mathrm{M}$ (Seale et al., 1988). DMPX did not affect evoked synaptic transmission (data not shown). When $1 S, 3 R$-ACPD (200 $\mu \mathbf{M})$ was bath applied with DMPX, typical reductions in the peak amplitudes of the synaptic responses were observed. PSPs to minimum stimulation were reduced to $48.1 \pm 24.6 \%$ of control amplitudes (Fig. $5 \mathrm{~A}$ ). The peak amplitude to maximum stimulation was reduced to $40.1+13.2 \%$ of control (Fig. $5 B$ ), and the late depolarizing response to maximum stimulation was reduced to $35.6 \pm 6.4 \%$ of control with $1 S, 3 R-A C P D$ (Fig. $5 C$ ). These data indicate that endogenous adenosine does not play a role in the synaptic depression mediated by $1 S, 3 R$-ACPD in the neocortex.

\section{$m G l u R$ activation reduces directly evoked IPSPS}

After blocking the excitatory components of evoked PSPs with the excitatory amino acid receptor antagonists 6-cyano-7-nitroquinoxaline-2,3-dione (CNQX) and $\mathrm{D}(-)$-2-amino-5-phosphonovaleric acid (D-AP5), we tested the effects of mGluR activation on IPSPs evoked by direct stimulation of interneurons. CNQX $(10 \mu \mathrm{M})$ blocks the non-NMDA receptor-mediated component, and D-AP5 $(20 \mu \mathrm{M})$ blocks the NMDA receptor-mediated component of neocortical EPSPs (Sutor and Hablitz, 1989a,b; Hablitz and Sutor, 1990). In Figure 6, $A$ and $B$ show control responses and those recorded during bath application of the EAA antagonists, respectively. The resulting PSPs were evoked at the same stimulus intensities used during the control period. PSPs evoked during EAA receptor antagonism reversed at membrane potentials near $-75 \mathrm{mV}$ (Fig. $6 \mathrm{C}$ ), indicating that they were $\mathrm{Cl}^{-}$-mediated GABAergic IPSPs (Connors et al., 1988; Sutor and Hablitz, 1989a; Hablitz and Sutor, 1990). Bath application of $50 \mu \mathrm{M} 1 S, 3 R$-ACPD (Fig. 6D) reduced the peak
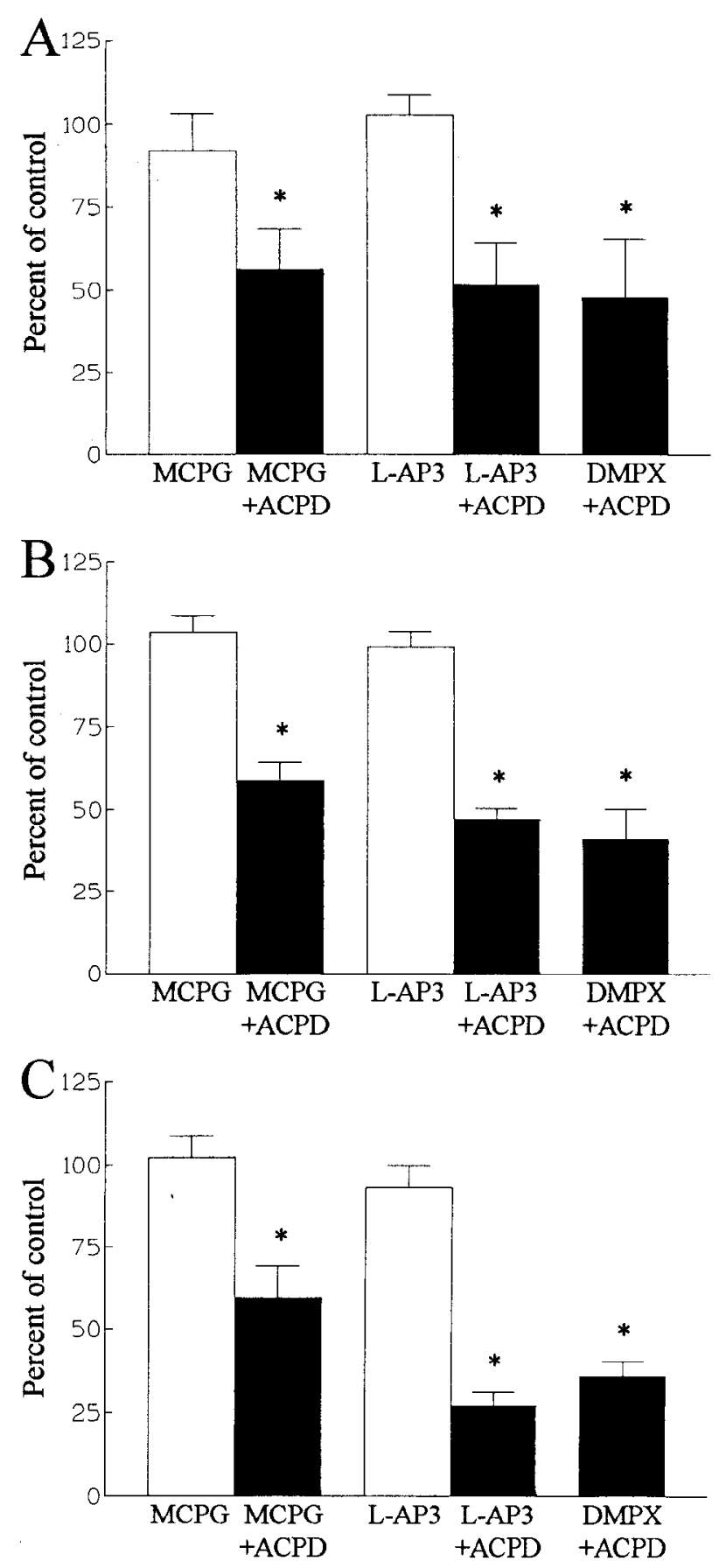

Figure 5. Alterations in PSPs following application of putative mGluR antagonists. The effects of MCPG, L-AP3, and DMPX on evoked synaptic transmission were tested. The percentage of control PSP amplitude to minimum stimulation $(A)$, peak amplitude to maximum stimulation $(B)$, and late depolarization to maximum stimulation $(C)$ during antagonist only and antagonist plus $1 S, 3 R$-ACPD $(100-200 \mu \mathrm{m})$ are illustrated. Means \pm SEM are displayed; $N=2-6$ for each treatment.

amplitude of the response to maximum stimulation to $56.4 \%$ of control. Results from all cells tested are shown in Figure $6 F$. The effect of $1 S, 3 R$-ACPD on directly evoked IPSPs was reversible upon washing out.

Quisqualic acid is a potent agonist for certain mGluR subtypes (Nakanishi, 1992; Schoepp, 1993; Schoepp and Conn, 1993). Because of its potent activation of non-NMDA receptors (Collingridge and Lester, 1989; Monaghan et al., 1989; Barnes and 

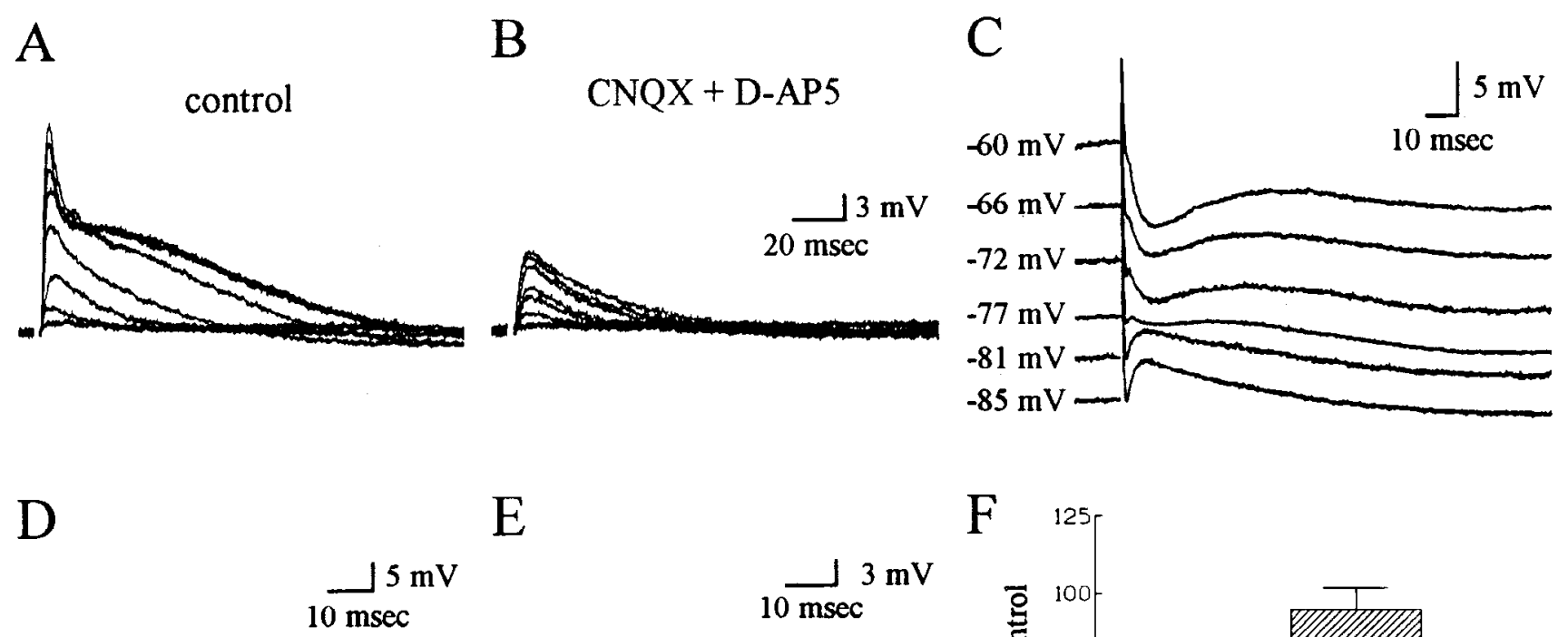

$\mathrm{E}$

$10 \mathrm{msec}$

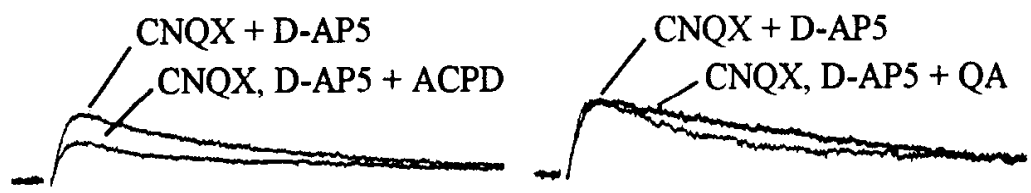

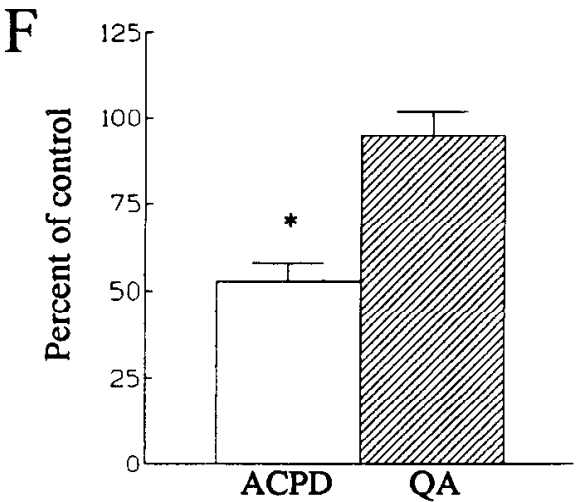

Figure 6. Directly evoked IPSPs in neocortical neurons are reduced by $1 S, 3 R$-ACPD, but not by quisqualic acid. $A$ and $B$, PSPs evoked under control conditions and in the presence of EAA receptor antagonists, respectively. The same stimulus intensities were used in $A$ and $B$. RMP was $-86 \mathrm{mV}$. C, Specimen records of PSPs obtained at different membrane potentials. Membrane potential was changed by injecting steady depolarizing current through the recording pipette; RMP was $-88 \mathrm{mV}$. The apparent reversal potential near $-75 \mathrm{mV}$ indicates that these are $\mathrm{Cl}^{-}$-mediated IPSPs (see Results). $D, 1 S, 3 R$-ACPD $(50 \mu \mathrm{M})$ reduced peak IPSP amplitude to $56.4 \%$ of control; RMP was $-86 \mathrm{mV}$. $E$, In a different neuron $(\mathrm{RMP}=-87 \mathrm{mV})$, application of quisqualic acid $(10 \mu \mathrm{M})$ did not depress peak IPSP amplitude. $F$, Means \pm SEM percentage of control for $1 S, 3 R$ ACPD (50-100 $\mu \mathrm{M}, N=6)$ versus quisqualic acid (1-10 $\mu \mathrm{M}, N=4)$ are illustrated.

Henley, 1992), we blocked ionotropic receptor subtypes with $10 \mu \mathrm{M}$ CNQX and $20 \mu \mathrm{M}$ D-AP5. Under these conditions, quisqualic acid (1-10 $\mu \mathrm{M}, N=4)$ did not alter directly evoked IPSPs. As shown in Figure $6 E$, peak IPSP amplitude was not reduced by $10 \mu \mathrm{M}$ quisqualic acid application (97.6\% of control). The mean effect of quisqualic acid on evoked IPSP amplitude is shown graphically next to that of $1 S, 3 R$-ACPD (Fig. $6 F$ ). No significant difference in IPSP amplitude or RMP was observed $(-85.3+2.1$ vs $-84.3 \pm 0.5 \mathrm{mV})$.

\section{Presynaptic locus of action}

Changes in synaptic efficacy producing a change in PSP amplitude might arise from two sources: (1) changes in the sensitivity of the postsynaptic site and/or (2) changes in the output of the presynaptic terminals. We investigated whether $1 S, 3 R-A C P D$ blocked spontaneous PSPs at concentrations that blocked evoked PSPs by about $50 \%$. In contrast to the effects on evoked synaptic transmission, 1S,3R-ACPD (50-200 $\mu \mathrm{M}, N=12)$ did not decrease the amplitude of spontaneous PSPs. Under control conditions, mean spontaneous PSP amplitude was $1.49 \pm 0.13 \mathrm{mV}$ (mean $\pm \mathrm{SEM}$ ); in the presence of $1 S, 3 R$-ACPD, the mean amplitude essentially was unchanged, $1.43 \pm 0.08 \mathrm{mV}$ (Fig. $6 A$ ). Consistent with a presynaptic sitc of action, drug application increased the mean spontaneous PSP interval from 17.54 $+7.14 \mathrm{sec}($ mean $\pm \mathrm{SEM})$ to $42.41 \pm 11.73 \mathrm{sec}$ (Fig. $6 \mathrm{~B})$. These observations suggest that $1 S, 3 R$-ACPD induces a presynaptic decrease in neurotransmitter release. The effects of $1 S, 3 R$-ACPD were reversible upon washing.

Paired pulse facilitation (PPF) is a phenomena seen at many chemical synapses and is generally thought to reflect a presynaptic enhancement in neurotransmitter release (Zucker, 1989). Manipulations that reduce transmitter release have been shown to increase PPF (Mallart and Martin, 1967; Katz and Miledi, 1968; Harris and Cotman, 1983). In the following set of experiments, a stimulus strength that evoked an EPSP was used. Interpulse intervals of 10-200 $\mathrm{msec}$ were tested, and the ratio of the second response amplitude to that of the first response was calculated. Control records were compared to those obtained during ACPD application. Exposure to $100 \mu \mathrm{M} 1 S, 3 R$ ACPD reduced the synaptic response by $39.5 \pm 20.9 \%(N=4)$, and enhanced PPF at all interstimulus intervals (data not shown). Because there is normally a greater percentage facilitation at smaller PSP amplitudes, PPF also was tested with an increased stimulus intensity that matched the conditioning PSP amplitude to that recorded during the control period. Under these conditions, facilitation remained increased at all interpulse intervals (data not shown). Statistically significant results were observed for intervals between 10 and $120 \mathrm{msec}$.

\section{Discussion}

Previous studies have shown that ACPD reduces synaptic transmission in a variety of brain regions (Baskys and Malenka, 1991; 
Crepel et al., 1991; Desai and Conn, 1991; Lovinger, 1991; Calabresi et al., 1992, 1993; Desai et al., 1992; Glaum and Miller, 1992; Glaum et al., 1992; Rainnie and Shinnick-Gallagher, 1992; Lovinger et al., 1993; Swartz et al., 1993). Our data demonstrate that metabotropic glutamate receptor activation in the adult rat neocortex produces a dose-dependent, reversible depression of synaptic transmission. Furthermore, these results indicate a presynaptic site of action for agonists working at mGluRs, presumably acting to decrease neurotransmitter release. Pharmacological profiles additionally suggest mGluR subtype-specific actions in the neocortex.

\section{Locus of $m$ GluR action}

Activation of neocortical mGluRs by $1 S, 3 R$-ACPD reduced the three measured components of evoked PSPs. Decreased synaptic transmission mediated by $1 S, 3 R$-ACPD could occur as the result of antagonism of a postsynaptic glutamate receptor, activation of a postsynaptic receptor that reduces $R_{\text {in }}$ of the cell, or the activation of a presynaptic receptor that reduces neurotransmitter release. The pharmacological profile of $1 S, 3 R$-ACPD makes antagonism of postsynaptic glutamate receptors unlikely. This compound is specific for mGluRs with no appreciable ionotropic glutamate receptor activity even at $\mathrm{mm}$ concentrations (Schoepp et al., 1991a; Sacaan and Schoepp, 1992). Additionally, under conditions of EAA receptor antagonism, directly evoked IPSPs were reversibly inhibited by $1 S, 3 R$-ACPD. This observation is consistent with the finding that mGluR responses are not antagonized by ionotropic EAA-receptor antagonists (Palmer et al., 1988; Recasens et al., 1988; Schoepp and Johnson, 1988), and indicates that 1S,3R-ACPD does not reduce synaptic transmission in the neocortex by antagonizing ionotropic glutamate receptors.

In most neurons examined, application of $1 S, 3 R$-ACPD did not decrease neuronal input resistance. To the contrary, higher concentration of $1 S, 3 R$-ACPD tended to increase $R_{\text {in }}$ in layer II-III neurons. Pooled data indicate a statistically significant trend toward a slight increase in $R_{\text {in }}$ and a small depolarization with $1 S, 3 R$-ACPD application. However, 1S,3R-ACPD-mediated depression of evoked synaptic transmission was observed in neurons that showed slight changes in $R_{\text {in }}$ and RMP, as well as those showing no change. Thus, it is unlikely that the changes in evoked PSPs are the result of alterations in passive membrane propertics sccondary to the activation of a postsynaptic receptor.

Our findings support the hypothesis that $1 S, 3 R$-ACPD acts via the activation of presynaptic mCluRs. The reduction in both ionotropic glutamate receptor-mediated transmission and GABAergic transmission by $1 S, 3 R$-ACPD strongly suggests a presynaptic locus of action, with $m$ GluR receptors present on both excitatory and inhibitory terminals. Direct evidence that $1 S, 3 R$ ACPD decreases synaptic transmission via a presynaptic action was obtained from investigations of spontaneous PSPs and paired-pulse facilitation of neocortical PSPs. At concentrations that reduced evoked PSPs by about 50\%, 1S,3R-ACPD did not reduce spontaneous PSP amplitude. However, the frequency of spontaneous PSPs was markedly decreased. These results are consistent with a presynaptic locus of action: $1 S, 3 R$-ACPD reduces transmitter release without changing postsynaptic responsiveness to transmitter. A postsynaptic receptor blocker would reduce responses produced by both stimulus-cvoked and spontaneous release of transmitter. In the neocortex, $1 S, 3 R$ ACPD enhances facilitation associated with paired-pulse stimulation. The observed increase in facilitation is an expected
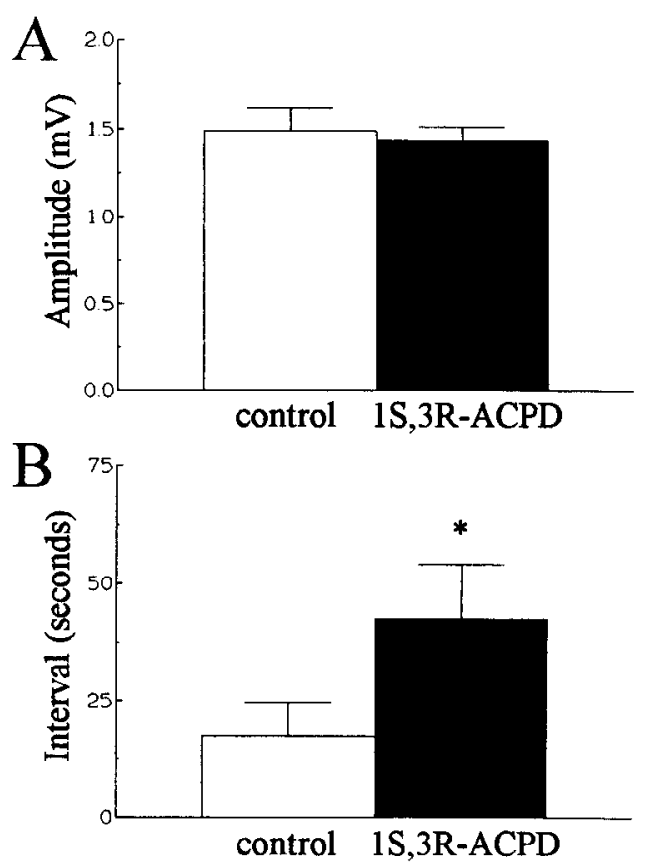

Figure 7. Modulation of spontaneous synaptic activity by $1 S, 3 R$-ACPD. $A$, Spontaneous PSP amplitudes are not affected by $50-200 \mu \mathrm{M} 1 S, 3 R$ ACPD. $B$, Interval between spontaneous events is markedly increased by $A C P D$ application. Means \pm SEM are presented.

consequence of decreasing transmitter release (Mallart and Martin, 1968). It is presumed that PPF is influenced by presynaptic $\mathrm{Ca}^{2+}$ ion availability (Zucker, 1989). Manipulations of extracellular $\mathrm{Ca}^{2+}$ concentrations that affect synaptic transmission has been shown to inversely affect PPF (Katz and Miledi, 1968; Mallart and Martin, 1968; Creager et al., 1980). Harris and Cotman (1983) suggest that this mechanism may be responsible for the actions of L-AP4 in the hippocampus. Recent reports indicate that mGluR activation by a variety of agonists can depress $\mathrm{Ca}^{2+}$ currents (Lester and Jahr, 1990; Sayer et al., 1992; Trombley and Westbrook, 1992; Swartz et al., 1993). The effects of ACPD and L-AP4 on synaptic transmission and PPF are consistent with a presynaptic decrease in a $\mathrm{Ca}^{2+}$ current involved in neocortical transmitter release (see Sayer et al., 1992; Swartz ct. al., 1993).

\section{Pharmacological profile for neocortical $m G / u R s$}

The activity of trans-ACPD is reportedly restricted to the $1 S, 3 R$ stereoisomer (Irving et al., 1990; Schoepp et al., 1991; but see Manzoni et al., 1992). In the adult rat neocortex, $1 S, 3 R$-ACPD reversibly reduced synaplic transmission in a dose-dependent manner. In the presence of $200 \mu \mathrm{M} 1 R, 3 S$-ACPD (a concentration of $1 S, 3 R$-ACPD that reduced PSPs by $>50 \%$ ), all evoked responses were within $90 \%$ of control values. Thus, the selective, presynaptic mGluR properties of trans-ACPD reside in the $1 S, 3 R$-stereo conformation.

L-AP4 has been touted as a putative mGluR antagonist (Schoepp and Johnson, 1988; Zheng and Gallagher, 1992), as well as an agonist at presynaptic glutamate autoreceptors (Harris and Cotman, 1983; Cotman et al., 1986; Forsythe and Clements, 1990; Baskys and Malenka, 1991; Rainnie and Shinnick-Gallagher, 1992; Trombley and Westbrook, 1992; Calabresi et al., 1993). Our findings that L-AP4 reduces synaptic transmission 
in the neocortex are consistent with the latter reports and, further, the suggestion that a mGluR subtype may be the electrophysiologically defined AP4 receptor (Nakanishi, 1992; Thomsen et al., 1992; Schoepp and Conn, 1993; Tanabe et al., 1993). However, two types of presynaptic glutamate receptors may exist, one that is sensitive to L-AP4 and ACPD, and another one that is sensitive to ACPD, but not to L-AP4 (Lovinger et al., 1993). Additionally, Sahara and Westbrook (1993) observed that ACPD and L-AP4 modulate $\mathrm{Ca}^{2+}$ currents via distinct G-protein-coupled receptors in hippocampal cultures. Such complexity could arise from regional variations in expression of mGluR subtypes and differential coupling to effector mechanisms. It is possible that more than one subtype is responsible for the presynaptic effects of $1 S, 3 R$-ACPD, which would explain the lower efficacy of L-AP4 versus $1 S, 3 R$-ACPD in the rat neocortex. Further investigations with subtype-specific agonists and antagonists will be required to elucidate the identity and the specific functions of the mGluR subtypes.

While L-glutamic acid is the most likely endogenous agonist for the mGluRs, quisqualic acid is a potent agonist for a number of mGluR subtypes (Nakanishi, 1992; Schoepp, 1993; Schoepp and Conn, 1993). We evaluated the possible activation of mGluRs by quisqualic acid in slices in which ionotropic EAA receptors were blocked. Under these conditions, we failed to observe statistically significant reductions in IPSP amplitude. However, quisqualic acid did enhance $R_{\text {in }}$ in all cells tested. It is possible that quisqualic acid does not activate the mGluR(s) responsible for presynaptically reducing PSP amplitude, but that this compound is a potent agonist for mGluRs located postsynaptically and therefore capable of increasing $R_{\mathrm{in}}$ in neocortical neurons in layers II-III.

Our studies with the putative mGluR antagonists MCPG and L-AP3 indicate that both compounds were poor antagonists of $1 S, 3 R$-ACPD-mediated synaptic depression in the neocortical slice. MCPG, however, was effective at blocking the direct postsynaptic effects of $1 S, 3 R$-ACPD (Burke and Hablitz, unpublished observations). Thus, MCPG may be an effective antagonist at postsynaptic mGluRs in the adult neocortex, but is less effective at presynaptically located mGluRs (see Frenguelli et al., 1993). The lack of pre-or postsynaptic antagonism by L-AP3 is consistent with most electrophysiological findings (Stratton et al., 1990; Charpak and Gähwiler, 1991; Desai et al., 1992; Glaum et al., 1992; Hu and Storm, 1992; Lovinger et al., 1993). This suggests that the mGluRs that are responsible for the reduction of synaptic transmission in the neocortex are not the same mGluRs that are L-AP3 sensitive and linked to PI hydrolysis (Schoepp and Johnson, 1989; Houamed et al, 1991; Desai et al., 1992), intracellular $\mathrm{Ca}^{2+}$ mobilization (Irving et al., 1990), or increased cAMP accumulation (Winder and Conn, 1993). However, our studies do not identify the mGluR-mediated second messenger system(s) involved in this form of synaptic modulation.

The functional role of the mGluRs in the adult neocortex is still unclear. It is obvious from this study that activation of these receptors has the functional consequences of presynaptic inhibition and postsynaptic excitation. Under "normal" conditions, these receptors may function at a low level to increase the signal to noise levels of synaptic responses. In pathologic situations, excessive mGluR activation may result, causing either excitatory or inhibitory consequences, depending on the receptor subtypes that are activated.

\section{References}

Abe T, Sugihara H, Nawa H, Shigemoto R, Mizuno N, Nakanishi S (1992) Molecular characterization of a novel metabotropic glutamate receptor mGluR5 coupled to inositol phosphate/Ca ${ }^{2+}$ signal transduction. J Biol Chem 267:13361-13368.

Aniksztein L, Otani S, Ben-Ari Y (1992) Quisqualic acid metabotropic receptors modulate NMDA currents and facilitate induction of longterm potentiation through protein kinase C. Eur J Neurosci 4:500505.

Anwyl R (1991) The role of the metabotropic receptor in synaptic plasticity. Trends Pharmacol Sci 12:324-326.

Aramori I, Nakanishi S (1992) Signal transduction and pharmacological characteristics of a metabotropic glutamate receptor, mGluR l, in transfected CHO cells. Neuron 8:757-765.

Barnes JM, Henley JM (1992) Molecular characteristics of excitatory amino acid receptors. Prog Neurobiol 39:113-133.

Bashir ZI, Bortolotto ZU, Davies CH, Beretta N, Irving AJ, Seal AJ, Henley JM, Jane DE, Watkins JC, Collingridge GL (1993) Induction of LTP in the hippocampus needs synaptic activation of glutamate metabotropic receptors. Nature 363:347-350.

Baskys A (1992) Metabotropic receptors and 'slow' excitatory actions of glutamate agonists in the hippocampus. Trends Neurosci 15:9296.

Baskys A, Malenka RC (1991) Agonists at metabotropic glutamate receptors presynaptically inhibit EPSCs in neonatal rat hippocampus. J Physiol (Lond) 444:687-701.

Burke JP, Hablitz JJ (1992) Modulation of synaptic potentials by metabotropic glutamate receptor activation in adult rat neocortex. Soc Neurosci Abstr 18:649.

Calabresi P, Mecuri NB, Bernardi G (1992) Activation of quisqualic acid metabotropic receptors reduces glutamate and GABA-mediated synaptic potentials in the rat striatum. Neurosci Lett 139:41-44.

Calabresi P, Pisani A, Mercuri NB, Benardi G (1993) Heterogeneity of metahotropic glutamate receptors in the striatum: electrophysiological evidence. Eur J Neurosci 5:1370-1377.

Cartmell J, Kemp JA, Alexander SPH, Kendall DA (1993) Endogenous adenosine regulates the apparent efficacy of 1 -aminocyclopentyl$1 S, 3 R$-dicarboxylate inhibition of forskolin-stimulated cyclic AMP accumulation in rat cerebral cortical slices. J Neurochem 60:780-782.

Calania MV, Aronica E, Sortino MA, Canonico PL, Nicoletti F (1992) Desensitization of metabotropic glutamate receptors in neuronal cultures. J Neurochem 56:1329-1335.

Charpak S, Gähwiler BH (1991) Glutamate mediates a slow synaptic response in hippocampal slice cultures. Proc R Soc Lond [Biol] 243 : 221-226.

Charpak S, Gähwiler BH, Do KQ, Knöpfel T (1990) Potassium conductances in hippocampal neurons blocked by excitatory amino-acid transmitters. Nature 347:765-767.

Collingridge GL, Lester RAJ (1989) Excitatory amino acid receptors in the vertebrate central nervous system. Pharmacol Rev 40:143-210.

Conn PJ, Desai MA (1991) Pharmacology and physiology of metabotropic glutamate receptors in mammalian central nervous system. Drug Dev Res 24:207-229.

Connors BW, Malenka RC, Silva LR (1988) Two inhibitory postsynaptic potentials and $G A B A_{4}$ and $G_{A B A}$ receptor-mediated responses in neocortex of rat and cat. $J$ Physiol (Lond) 406:443-468.

Cotman CW, Hlatman JA, Ganong AH, Perkins MH (1986) Effects of excitatory amino acid antagonists on evoked and spontaneous excitatory potentials in guinea-pig hippocampus. J Physiol (Lond) 378:403-415.

Creager R, Dunwiddie T, Lynch G (1980) Paired-pulse and frequency facilitation in the CAl region of the in vitro rat hippocampus. J Physiol (Lond) 299:409-424.

Crepel F, Daniel H, Hemart N, Jaillard D (1991) Effects of ACPD and AP3 on parallel-fibre-mediated EPSPs of Purkinje cells in cerebellar slices in vitro. Exp Brain Res 86:402-406.

Desai MA, Conn PJ (1991) Excitatory effects of ACPD receptor activation in the hippocampus are mediated by direct effects on pyramidal cells and blockade of synaptic inhibition. J Neurophysiol 68 : $40-52$.

Desai MA, Smith TS, Conn PJ (1992) Multiple metabotropic glutamate receptors regulate hippocampal function. Synapse 12:206-213.

Eaton SA, Jane DE, Jones PLStJ, Porter RHP, Pook PC-K, Sunter DC, Udvarhelyi PM, Roberts PJ, Salt TE, Watkins JC (1993) Compet- 
itive antagonism at metabotropic glutamate receptors by $(S)$-4-carboxyphenylglycine and $(R S)$ - $\alpha$-methyl-4-carboxyphenylglycine. Eur J Pharmacol 244:195-197.

Fagni L, Bossu JL, Bockaert J (1991) Activation of a large-conductance $\mathrm{Ca}^{2+}$-dependent $\mathrm{K}^{+}$channel by stimulation of glutamate phosphoinositide-coupled receptors in cultured cerebellar granule cells. Eur J Neurosci 3:778-789.

Forsythe ID, Clements JD (1990) Presynaptic glutamate receptors depress excitatory monosynaptic transmission between mouse hippocampal neurones. J Physiol (Lond) 429:1-16.

Frenguelli BG, Potier B, Slater NT, Alford S, Collingridge GL (1993) Metabotropic glutamate receptors and calcium signalling in dendrites of hippocampal CA1 neurons. Neuropharmacology 32:1229-1237.

Glaum SR, Miller RJ (1992) Metabotropic glutamate receptors mediate excitatory transmission in the nucleus of the solitary tract. $J$ Neurosci 12:2251-2258.

Glaum SR, Slater NT, Rossi DJ, Miller RJ (1992) Role of metabotropic glutamate (ACPD) receptors at the parallel fiber-Purkinje cell synapse. J Neurophysiol 68:1453-1462.

Hablitz JJ, Sutor B (1990) EPSPs in rat neocortical neurons in vitro. III. Effects of a quinoxalinedione non-NMDA receptor antagonist. J Neurophysiol 64:1282-1290.

Harris EW, Cotman CW (1983) Effects of acidic amino acid antagonists on paired-pulse potentiation at the lateral perforant path. Exp Brain Res 52:455-460.

Hayashi Y, Momiyama A, Takahashi T, Ohishi H, Ogawa-Meguro R, Shigemoto R, Mizuno N, Nakanishis (1993) Role of a metabotropic glutamate receptor in synaptic modulation in the accessory olfactory bulb. Nature 366:687-690.

Houamed KM, Kuijper JL, Gilbert TL, Haldeman BA, O'Hara PJ, Mulvihill ER, Almers W, Hagen FS (1991) Cloning, expression, and gene structure of a $G$ protein-coupled glutamate receptor from rat brain. Science 252:1318-1321.

Hu G-Y, Storm JF (1992) 2-Amino-3-phosphonopropionate fails to block postsynaptic effects of metabotropic glutamate receptors in rat hippocampal neurons. Acta Physiol Scand 145:187-191.

Irving AJ, Schofield JG, Watkins JC, Sunter DC, Collingridge GL (1990) $1 S, 3 R$-ACPD stimulates and L-AP3 blocks $\mathrm{Ca}^{2+}$ mobilization in rat cerebellar neurons. Eur J Pharmacol 186:363-365.

Izumi Y, Clifford DB, Zorumski CF (1991) 2-Amino-3-phosphonopropionate blocks the induction and maintenance of long-term potentiation in rat hippocampal slices. Neurosci Lett 122:187-190.

Jane DE, Jones PL, Pook PC, Salt TE, Sunter DC, Watkins JC (1993) Stereospecific antagonism by $(+)$-alpha-methyl-4-carboxyphenylglycine (MCPG) of $(1 S, 3 R)$-ACPD-induced effects in neonatal rat motoneurones and rat thalamic neurones. Neuropharmacology 32:725727.

Katz B, Miledi R (1968) The role of calcium in neuromuscular facilitation. J Physiol (Lond) 195:481-492.

Linden DJ, Dickinson MH, Smeyne M, Conner JA (1991) A longterm depression of AMPA currents in cultured cerebellar Purkinje neurons. Neuron 7:81-89.

Lonart G, Alagarsamy S, Ravula R, Wang J, Johnson KM (1992) Inhibition of the phospholipase C-linked metabotropic glutamate receptor by 2-amino-3-phosphonopropionate is dependent on extracellular calcium. J Neurochem 59:772-775.

Lovinger DM (1991) Trans-1-aminocyclopentane-1,3-dicarboxylic acid (t-ACPD) decreases synaptic excitation in rat striatal slices through a presynaptic action. Neurosci Lett 129:17-21.

Lovinger DM, Tyler E, Fidler S, Merritt A (1993) Properties of a presynaptic metabotropic glutamate receptor in rat neostriatal slices. J Neurophysiol 69:1236-1244.

Mallart A, Martin AR (1967) An analysis of facilitation of transmitter release at the neuromuscular junction of the frog. J Physiol (Lond) 193:679-694.

Manzoni O, Prezeau L, Rassendren FA, Sladeczek F, Curry K, Bockaert J (1992) Both isomers of 1-aminocyclopentane-1,3-dicarboxylate are full agonists of metabotropic glutamate receptors coupled to phospholipase C. Mol Pharmacol 42:322-327.

Martin LJ, Blackstone CD, Huganir RL, Price DL (1992) Cellular localization of a metabotropic glutamate receptor in rat brain. Neuron 9:259-270

Masu M, Tanabe Y, Tsuchida K, Shigemoto R, Nakanishi S (1991) Sequence and expression of a metabotropic glutamate receptor. Nature 349:760-765.
Monaghan DT, Bridges RJ, Cotman CW (1989) The excitatory amino acid receptors: their classes, pharmacology, and distinct properties in the function of the central nervous system. Annu Rev Pharmacol Toxicol 29:365-402.

Nakajima Y, Iwakabe H, Akazawa C, Nawa H, Shigemoto R, Mizuno $N$, Nakanishi S (1993) Molecular characterization of a novel retinal metabotropic glutamate receptor mGluR 6 with a high agonist affinity for L-2-amino-4-phosphonobutyrate. J Biol Chem 268:11868-11873.

Nakanishi S (1992) Molecular diversity of glutamate receptors and implications for brain function. Science 258:597-603.

Ohishi H, Shigemoto R, Nakanishi S, Mizuno N (1993) Distribution of the messenger RNA for a metabotropic glutamate receptor, mGluR2, in the central nervous system. Neuroscience 53:1009-1018.

Palmer E, Monaghan DT, Cotman CW (1988) Glutamate receptors and phosphoinositide metabolism: stimulation via quisqualate receptors in inhibited by $N$-methyl-D-aspartate receptor activation. Mol Brain Res 4:161-165

Prezeau L, Manzoni O, Homburger V, Sladeczek F, Curry K, Bockaert J (1992) Characterization of a metabotropic glutamate receptor direct negative coupling to adenylyl cyclase and involvement of a pertussis toxin-sensitive $G$ protein. Proc Natl Acad Sci USA 89:80408044.

Prince DA, Stevens CF (1992) Adenosine decreases neurotransmitter relcase at central synapses. Proc Natl Acad Sci USA 89:8586-8590.

Rainnie DG, Shinnick-Gallagher P (1992) Trans-ACPD and L-APB presynaptically inhibit excitatory glutamatergic transmission in the basolateral amygdala (BLA). Neurosci Lett 139:87-91.

Recasens M, Guiramand J, Naourigat A, Sassetti I, Devilliers G (1988) A new quisqualate receptor subtype ( $\mathrm{sAA}_{2}$ ) responsible for the glutamate-induced inositol phosphate formation in rat brain synaptoneurosomes. Neurochem Int 13:463-467.

Sacaan AI, Schoepp DD (1992) Activation of hippocampal metabotropic excitatory amino acid receptors leads to seizures and neuronal damage. Neurosci Lett 139:77-82.

Sahara Y, Westbrook GL (1993) Modulation of calcium currents by a metabotropic glutamate receptor involves fast and slow kinetic components in cultured hippocampal neurons. J Neurosci 13:30413050 .

Saugstad JA, Kinzie JM, Segerson TP, Westbrook GL (1993) Characterization of a new metabotropic glutamate receptor homologous to the AP4 receptor. Soc Neurosci Abstr 19:68.

Sayer RJ, Schwindt PC, Crill WE (1992) Metabotropic glutamate receptor-mediated suppression of L-type calcium current in acutely isolated neocortical neurons. J Neurophysiol 68:833-842.

Schoepp DD (1993) The biochemical pharmacology of metabotropic glutamate receptors. Biochem Soc Transact 21:97-102.

Schoepp DD, Conn PJ (1993) Metabotropic glutamate receptors in brain function and pathology. Trends Pharmacol Sci 14:13-20.

Schoepp DD, Johnson BG (1988) Excitatory amino acid agonist-antagonist interactions at 2-amino-4-phosphonobutyric acid-sensitive quisqualate receptors coupled to phosphoinositide hydrolysis in slices of rat hippocampus. J Neurochem 50:1605-1613.

Schoepp DD, Johnson BG (1989) Inhibition of excitatory amino acidstimulated phosphoinositide hydrolysis in neonatal rat hippocampus. J Neurochem 53:1865-1870

Schoepp D, Bockaert J. Sladeczek F (1990) Pharmacological and functional characteristics of metabotropic excitatory a mino acid receptors. Trends Pharmacol Sci 11:508-515.

Schoepp DD, Johnson BG, Salhoff CR, McDonald JW, Johnston MV (1991a) In vitro and in vivo pharmacology of trans- and cis-(+)-1amino-1,3-cyclopentanedicarboxylic acid: dissociation of metabotropic and ionotropic excitatory amino acid receptor effects. J Neurochem 56:1789-1796.

Schoepp DD, Johnson BG, True RA, Monn JA (1991b) Comparison of $(1 S, 3 R)$-1-aminocyclopentane-1,3-dicarboxylic acid $(1 S, 3 R$ ACPD)- and $1 R, 3 S$-ACPD-stimulated brain phosphoinositide hydrolysis. Eur J Pharmacol 207:351-353.

Seale TW, Abla KA, Shamim MT, Carney JM, Daly JW (1988) 3,7Dimethyl-1-propargylxanthine: a potent and selective in vivo antagonist of adenosine analogs. Life Sci 43:1671-1684.

Shigemoto R, Nakanishi S, Mizuno N (1992) Distribution of the mRNA for a metabotropic glutamate receptor (mGluR1) in the central nervous system: an in situ hybridization study in adult and developing rat. J Comp Neurol 322:121-135.

Stratton KR, Worley PF, Baraban JM (1989) Excitation of hippocam- 
pal neurons by stimulation of glutamate $Q_{p}$ receptors. Eur J Pharmacol 173:235-237.

Stratton KR, Worley PF, Baraban JM (1990) Pharmacological characterization of phosphoinositide-linked glutamate receptor excitation in hippocampal neurons. Eur J Pharmacol 186:357-361.

Sutor B, Hablitz JJ (1989a) EPSPs in rat neocortical neurons in vitro. I. Electrophysiological evidence for two distinct EPSPs. J Neurophysiol 61:607-620.

Sutor B, Hablitz JJ (1989b) EPSPs in rat neocortical neurons in vitro II. Involvement of $N$-methyl-D-aspartate receptors in the generation of EPSPs. J Neurophysiol 61:621-634.

Swartz KJ, Merritt A, Bean BP, Lovinger DM (1993) Protein kinase $\mathrm{C}$ modulates glutamate receptor inhibition of $\mathrm{Ca}^{2+}$ channels and synaptic inhibition. Nature 361:165-168.

Tanabe Y, Masu M, Ishii T, Shigemoto R, Nakanishi S (1992) A family of metabotropic glutamate receptors. Neuron 8:169-179.

Tanabe Y, Nomura A, Masu M, Shigemoto R, Mizuno N, Nakanishi S (1993) Signal transduction, pharmacological properties, and expression patterns of two rat metabotropic glutamate receptors, mGluR3 and mGluR4. J Neurosci 13:1372-1378.

Thompson SM, Haas HL, Gähwiler BH (1992) Comparison of the actions of adenosine at pre- and postsynaptic receptors in the rat hippocampus in vitro. J Physiol (Lond) 451:347-363.

Thomsen C, Kristensen P, Mulvihill E, Haldeman B, Suzdak PD (1992)

L-2-Amino-4-phosphonobutyrate (L-AP4) is an agonist at the type IV metabotropic glutamate receptor which is negatively coupled to adenylate cyclase. Eur J Pharmacol 227:361-362.

Trombley PQ, Westbrook GL (1992) L-AP4 inhibits calcium currents and synaptic transmission via a G-protein-coupled glutamate receptor. J Neurosci 12:2043-2050.

Winder DG, Conn PJ (1993) Activation of metabotropic glutamate receptors increases cAMP accumulation in hippocampus by potentiating responses to endogenous adenosine. J Neurosci 13:38-44.

Yoon K-W, Rothman SM (1991) Adenosine inhibits excitatory but not inhibitory synaptic transmission in the hippocampus. J Neurosci 11:1375-1380.

Zheng F, Gallagher JP (1992) Metabotropic glutamate receptors are required for the induction of long-term potentiation. Neuron 9:163172.

Zucker RS (1989) Short-term synaptic plasticity. Annu Rev Neurosci $12: 13-31$ 